\title{
New Normal dan Kebijakan Pendidikan
}

\section{Abdurrahim \\ Program studi pendidikan IPS, FKIP Universitas lambung mangkurat 1810128210014 1810128210014@mhs.ulm.ac.id}

\begin{abstract}
Abstrak
Di masa covid-19 ini banyak memunculkan berbagai macam aktivitas baru yang berdampak tidak hanya dari satu atau dua bidang saja akan tetapi berdampak pada semua bidang, dengan adanya wabah ini aktivitas manusia seolah terhenti oleh waktu. Permasalahan yang muncul akibat covid-19 yang dapat kita rasakan saat ini pada bidang perekonomian dan juga pendidikan yang mengaharuskan karyawana ataupun guru berkerja di rumah saja akibat kondisi yang dialami yang memunculkan pro dan kontra untuk sebagian orang. Tulisan ini bertujuan agar memberi pandangan kepada sipembaca terhadap isu yang sedang terjadi aaat ini dan juga memberikan sebuah pemikiran guna melakukan keajiban terhadap tugas dari dosen untuk syarat UAS.

Kata Kunci : Covid-19, New Normal, Pendidkan, dan Kebijakan
\end{abstract}

\section{Pendahuluan}

Corona Virus Diseases 2019 atau disebut dengan nama lain Covid-19 menjadi permasalahan yang banyak menyoroti perhatian masyarakat di berbagai belahan dunia. Sejak pertama sekali diketahui dari pasien yang terinfeksi Covid-19 di Wuhan, Provinsi Hubei, Cina pada 8 Desember 2019, kini virus ini telah menyebar ke 216 negara. Pandemi Covid-19 ini tidak hanya mengancam kesehatan manusia, namun juga telah memengaruhi kemerosotan ekonomi dunia pada bidang tertentu seperti yang dapat kita lihat sektor yang paling terdampak pada pendemi ini adalah penerbangan, transportasi, hotel, dan restoran bahkan tidak jarang pedang-pedang kecil juga mendapatkan dampak dari adanya pendemi ini karena guna menghindari penyebaran virus yang terus menerus pemerintah Indonesia juga melakukan penutupan untuk beberapa pasar guna pencegahan virus tersebut.

Dalam hal seperti ini tentunyab pemerintahan juga sudah mengambil berbagai kebijakan di mana salah satu diantaranya adalah memutuskan tentang aktivitas yang dulunya dilakukan diluar rumah kini beralih cukup dilakukan di rumah saja seperti bekerja, belajarm dan beribadah, kebijakan ini dikenal dikalanagan masyarakat dengan 
istilah Work From Home. Tidak hanya sampai disitu pembatasan sosial berskala besar (PSBB) juga dilakukan oleh pemerintah guna mengahambat rantai penularan Covid-19 dari Daerah - daerah yang sudah terkontaminasi oleh virus ini (Abbas, E. W. (2020). Berbagai penelitian terus dilakukan oleh para peneliti untuk menemukan vaksin covid19. Namun hingga saat ini obat penyembuh covid-19 belum ditemukan dan belum dapat diprediksi kapan vaksin tersebut ditemukan. Kondisi ambigu juga muncul ketika prediksi para ilmuan kapan Covid-19 bisa berakhir. Permasalahan ini menjadi perhatian penting bagi pemerintah sehingga pemerintah perlu mengambil kebijakan guna memperbaiki kondisi Indonesia tetap produktif, namun tetap mematuhi protokol kesehatan.

Saat ini, Indonesia telah memasuki fase baru dalam penanganan covid-19, yaitu new normal. Suatu kondisi di mana masyarakat kembali dapat beraktivitas, bekerja, beribadah seperti biasa, namun dengan desain yang baru. Berbagai protokol menyambut era new normal telah dipersiapkan oleh pemerintah, termasuk dalam tatanan birokrasi guna memberikan pelayanan publik di era Covid-19. Pada bidang lainnya yaitu Pendidikan merupakan alat yang sangat penting bagi setiap bangsa untuk mencari jati diri dan meningkatkan daya saing. Maka dari itu negara harus memfasilitasi pelayanan pendidikan bermutu kepada setiap warganya tanpa terkecuali, termasuk warganya yang memiliki kebutuhan khusus (Syaharuddin, S,. 2020). Permasalahan yang muncul ditengah - tengah pendemi ini juga terdapat pada bidang pendidikan yang mana dengan adanya pendemi ini tidak hanya merubah kegiatan pada sektor perekonomian saja akan tetapi juga berdampak pada sistem pendidikan yang dilakukan secara daring. Dimana peserta didik tidak perlu melakukan pembelajaran secara tatap muka akan tetapi hanya duduk di rumah didepan kamera leptop/handphone.

Dalam kasus ini, penting rasanya sebuah kebijakan/regulasi guna menata ulang kehidupan yang ada di lingkungan masyarakat dengan kebiasaan baru khususnya di negara Indonesia ini guna menjawab tantangan yang ada. Tulisan ini bertujuan untuk mengulas perubahan sistem di era new normal melalui pendekatan model perubahan organisasi. Perubahan sistem memerlukan ide-ide kreatif yang dikembangkan melalui sebuah inovasi dalam pelayanan pendidikan yang memadai dan terfasilitasi dengan baik, tanpa kendala meskipun dalam kondisi pandemi Covid-19. Oleh karena itu, tulisan ini juga mengulas tentang regulasi new normal apakah merupakan keputusan yang tepat atau tidak di era pendimi covid-19 ini.

\section{Pembahasan}


Covid-19 menyebar ketakutan Pada akhir tahun 2019 dunia digemparkan dengan kedatangan virus yang barang siapa terinfeksi mampu menggetarkan seluruh negara yang dilanda, virus yang datang dari negara China Wuhan pada awal desember 2019 dimana pada saat itu sejumlah orang berdatangan ke rumah sakit guna mencek apa yang sebenarnya terjadi. Hal ini terus berlanjut pada awal tahun 2020 china mengumumkan sebuah virus yang belum terditeksi akan kebredaannya setelah beberapa hari kedepan jumlah kasus pun meningkat sehingga perlu penangan khusus untuk mengatasinya. Menyusul dari Thailand mengkonfirmasi bahwa ada satu orang terinfeksi, tidak lama berselama Jepang juga melaporkan hal yang sama dan wabah pun tersebar ke berbagai negara bahkan di tempat asal virus tersebut pun mengalami kenaikan orang yang terinfeksi semakin bertambah hari demi hari dan diiringi dengan jumlah yang meninggal juga meningkat. Hal ini cukup menakutkan beberapa negara, puncaknya virus ini ditakuti saat virus masuk ke kota Italia yang awalnya hanya meremehkan virus tersebut.

Tidak lama berlangsung setiap negara berantisifasi terlebih dahulu dengan cara menutup akses keluar negri guna mencegah tersebarnya virus bahkan sampai menutup beberapa Universtias. Ketakutan pun tersebar ke mana - mana yang menimbulkan kebijakan baru di masa pendemi yang tidak hanya berdampak pada satu bidang saja akan tetapi ke semua bidang seperti ekonomi dan pendidikan. Saat tinggi - tingginya masyarakat yang terkontaminasi dengan virus covid-19 yang semakin bertambah di mana puncaknya terjadi pada Maret 2020 sampai berakhirnya bulan April yang mengharuskan pemerintah mengeluarkan regulasi/kebijakan WFH (work from home) agar memutus rantai penyebaran virus yang semakin bertambah semakin banyak selain itu, hal ini juga menimbulkan keluarnya kebijakan yang dikeluarkan oleh mentri pendidikan yang mengharuskan sekolah hingga universitas ditutup dan belajar secara online atau daring (Syaharuddin, S. (2020).

\section{Fase Awal corona virus-19 di Indonesia}

Pada tahap awal indonesia terinfeksi terkena virus covid -19 indonesia masing tenag menghadapa karena pemerintah menganggap bahwa itu hanya virus flu semata, setelah pertengahan februaari hingga akhir april di Indonesia mengalami kenaikan tinggi yang sangat dratis yang mengakibatkan pemerintahan Indonesia mengeluarkan kebijakan lockdown Di beberapa daerah yang beresiko tinggi tertular covid-19. Setelah beberapa bulan lockdown Indonesia mengalami penurunan dibidang ekonomi di mana hal ini menimbulkan kekhawatiran yang tinggi karena bisa menimbulkan keributan pada masyarakat akibat tingginya angkat kemiskinan yang terjadi akibat lockdown, puncaknya pada akhir april indonesia mengalami dilema karena kebingungan dengan 
kondisi yang melanda. Kenapa tidak, dengn adanya pemberlakuan PSBB semakin membuat masyarakat kesulitan mencari nafkah yang memicu masyarakat berontak dan tidak mematuhi kebijakan yang dikeluarkan oleh pemerintah.

Tidak lama setelah hal tersebut dan turunnya perekonomian mendesak pemerintah membuat kebijakan baru guna menanggulangi kondisi yang terjadi Di Indonesia, yah kebijakan baru tersebut adalah New Normal. New Normal mepukan sebuah kebijakan yang dilakukan oleh pemerintah di mana masyarakat beraktivitas seperti biasa dengan beberapa protokol kesehatan yang sudah ditetapkan oleh kesehatan dunia dan selalu memakai masker, tentunya hal ini merupakan hal baru di mana kita di tuntut agar menajga kesehatan dan menjaga jarak terhadap individu lainnya. Hal ini pastinya sudah dilakukan berbagai macam pertimbangan mengingat turunnya nilai ekonomi di Indonesia. Pada tahapan ini seharusnya dari pemerintah melalkukan thapan yang mungkin bisa dimulai dari wilayah yang sudah lama lockdown disusul daerah dibelakangnya atau bisa juga di mulai dari kondisi darah yang sedikit positif. Akan tetapi adanya masyarakat yang tidak terlalu patuh terhadap kebijakan yang ada juga menghambat jalannya kondisi yang diharapkan (aman) terbukti dengan semakin meningkatnya jumlah yang positif terkena covid - 19 (WARMANSYAH ABBAS, E. R. S. I. S. (2020).

\section{Metode baru dalam dunia pendidikan}

Pada awal tahun 2020 dunia dilanda virus yang mengemparlan dunia, mengapa tidak setelah datangnya virus ini seluruh negara yang terdampak virus tersebut mengalami berbagai macam perubahan di beberapa bidang, salah satunya adalam bidang pendidikan di mana sejak lama saya bersekolah belum pernah menemui pembelajaran online/daring yang secara tidak sadar merubah sistem yang sudah dirancang guru berubah menajdi hal yang mungkin saja tidak tercapai. Kondisi seperti ini juga membuat beberapa guru terkejut dan tidak terbiasa dengan sistem pembelajaran yang berubah, selama kurang lebih 3 bulan sekolah dialihkan ke sistem pembelajaran daring/online bagaimana tidak, selama puluhan tahun dengan bangga guru mengajar secara konvensional. Menjelaskan materi demi materi yang kadang baik mahasiswa atapun peserta didik paham, walau tampaknya lebih banyak yang tidak paham. Kini, para guru harus mengoperasionalkan sebuah aplikasi yang berbasis online yang belum dilakukan sebelumnya. Dosis lain hal ini juga menajdi sebuah tantangan tersendiri bagi seorang guru. Apalagi dengan kemajuan teknologi yang ada pada saat ini. 
Dalam konteks ini, seorang guru haruslah menjadi manusia pembelajar. Dengan menjadi manusia pembelajar, maka kita sebagai calon guru dapat terus eksis disegala terpaan. Di tengah pandemi Covid-19, maka dari itu sebagai seorang pendidik harus belajar teknologi dan mengaplikasikannya untuk dapat bertahan paling tidak dalam profesinya menajdi seorang sebagai pendidik yang mengharuskan belajar secara daring melalui aplikasi, baik via zoom, google meet dan google classroom (Syaharuddin, S, 2020). Dalam kasus ini tidak menutup kemungkinan banyak kendala yang terjadi saat pembelajaran dikarenakan kondisi di setiap wilayah yang berbeda bahkn ada juga yang kesusahan dalam melakukan pembelajaran berikut ada banyak kendala yang dihadapi mulai dari teknis perkuliahan, koneksi yang terkadang bisa menghilang dikala listrik mati bagi daerah pedalaman, menggunakan serana (zoom, google meet, google calassroom) dengan benar seperti menghidupkan speker saat dosen atau guru menjelaskan, cara melakukan sebuah presenting sereta kurangnya pasrtisipasi peserta didik/mahasiswa.

\section{Simpulan}

Pada dasarnya setiap pemimpin menginginkan masyarakatnya makmur dan sajehtera saat kepemimpinannya berlangsung, namun tentunya tidaklah semudah apa yang dipikirkan dan diharapkan pada kenyataannya sangat jauh dengan fakta lapangan. Belum lagi kondisi yang terkadang tidak mendukung seperti saat ini di mana Indonesia sedang tinggi - tingginya angka positif yang semakin bertambah setiap harinya yang mengharuskan pemerintah melakukan berbagai macam cara dengan mengeluarkan beberapa kebijakan yang tentunya hal tersebut hanya untuk warga negaranya agar tidak semakin banyak yang positif.

Pada tahap awal indonesia mengeluarkan kebijakan lockdown sejak bulan April yang mana bertujuan untuk memutus mata rantai virus covid-19 menimbulkan berbagai macam pro dan kontra yang terjadi seperti penutupan mesjid hingga berkerja melalui rumah. Disusul dengan kebijakan Work From Home yang berdampak pada bidang perekonomian dan juga pendidikan hingga akhir juni, setelah itu pemerintahan kembali mengeluarkan kebijakan New normal yang diterapkan saat ini.

\section{Daftar Pustaka}

Abbas, E. W. (2020). Menulis di Otak dan Menuliskan Tulisan di Otak..

Abbas, E. W., Hadi, S., \& Rajiani, I. " GURU SEKUMPUL" AS THE PROPHETICAL MODEL OF ENTREPRENEURSHIP EDUCATION FROM ISLAMIC PERSPECTIVE. 
Harlie, M., Rajiani, I., \& Abbas, E. W. (2019). Managing information systems by integrating information systems success model and the unified theory of acceptance and usage of technology. Polish Journal of Management Studies, 20.

Nasih, M., Abbas, E. W., \& Syaharuddin, S. (2019). NILAI-NILAI HAUL GURU SEKUMPUL SEBAGAI SUMBER BELAJAR IPS. Jurnal Socius, 8(2).

Subiyakto, B., Kot, S., \& Syaharuddin, S. (2020). The government reform on healthcare facilities from the standpoint of service quality performance. INTERNATIONAL JOURNAL OF ECONOMICS AND FINANCE, 12(1).

Syaharuddin, S. (2020). Menimbang Peran Teknologi dan Guru dalam Pembelajaran di Era COVID-19. Menimbang Peran Teknologi dan Guru dalam Pembelajaran di Era COVID-19.

Syaharuddin, S. (2020). PEMBELAJARAN MASA PANDEMI: DARI KONVENSIONAL KE DARING. PEMBELAJARAN MASA PANDEMI: DARI KONVENSIONAL KE DARING.

Syaharuddin, S., \& Mutiani, M. (2020). STRATEGI PEMBELAJARAN IPS: Konsep dan Aplikasi.

Wahyuningsih, S., Abbas, E. W., \& Mutiani, M. (2020). Implementation of Leadership Value of Rudy Resnawan as a Learning Resources on Social Studies. The Innovation of Social Studies Journal, 1(2), 169-177.

WARMANSYAH ABBAS, E. R. S. I. S. (2020). Menulis di Era Covid-19: Memanage Trauma Psikologis Menghindari Psikosomatis. Menulis di Era Covid-19: Memanage Trauma Psikologis Menghindari Psikosomatis. 